\title{
The energy and protein value of double-low rape seeds for growing pigs
}

\section{Stanisława Raj, H. Fandrejewski, Mąria Kotarbińska and Katarzyna Chabiera}

The Kielanowski Institute of Animal Physiology and Natrition, Polish Academy of Sciences 05-110 Jablonna, Poland

(Received 11 June 1993; accepted 21 June 1993)

\section{ABSTRACT}

Groups of 12 growing Landrace pigs with an average body weight of $55 \pm 1.5 \mathrm{~kg}$ were fed a diet containing from 5 to $30 \%$ (Expt. 1) or 0 to $25 \%$ (Expt. 2) raw rape seeds. The digestibility of the diet was determined by either the indicator method (Expt. 1) or total collection method (Expt. 2). Metabolizability of energy was also determined in experiment 2. The apparent digestibility of crude protein was not dependent on the proportion of rape seeds in the diet, whereas the digestibility and metabolizability of energy decreased after the rape seed content exceeded $15 \%$ (Expt. 2) or $20 \%$ (Expt. 1). The mean coefficient of digestibility and metabolizability of energy and apparent digestibility of protein determined by multiple equations when the rape seed content equalled to 15 and $20 \%$, were: $76.1 \pm 1.8 \%, 66.4 \pm 2.4 \%$ and $75.8 \pm 3.5 \%$, respectively. The digestible and metabolizable energy contents and digestible protein content in $1 \mathrm{~kg}$ DM of seeds were, respectively: 22.4. 20.2 $\mathrm{MJ}$ and $156 \mathrm{~g}$.

KEY WORDS: rape sceds, metabolizable energy, protein digestibility, growing pigs

\section{INTRODUCTION}

Increased cultivation of ,, $00^{\prime \prime}$ varieties of rape (with glucosinolate contents below $30 \mu \mathrm{mol} / \mathrm{g}$ fat-free DM) presents an opportunity to use raw rape seed (RS) and oil meal on a wider scale in the feeding of monogastric animals. RS from " 00 " cultivars contains approximately $40 \%$ ether extract and $20 \%$ protein and is a potential source of dietary energy and protein for pigs.

There have been few studies on the nutritive value of "00" cultivars for pigs. In experiments of Salo (1980) and Bourdon et al. (1990) protein digestibility varied widely, from 68.9 to $83.7 \%$, while the digestibility of energy was $83.7 \%$ (Bourdon et al., 1990). Other authors (e.g. Ochetim et al., 1980; Show et al., 1990) 
reported, that diets with a high RS content (from 15 to $30 \%$ ) were less digestible to pigs than diets without RS. This suggests that such components of RS as glucosinolates, fibre and fatty acids introduced into the diet in excessive amounts can have a deleterious effect on its nutritive value.

The main objective of the study was to give more information on the nutritive value of low-glucosinolate rape seeds for pigs. The influence of various proportion of RS in the diet on the apparent digestibility of protein and energy and metabolizability of energy was investigated.

\section{MATERIAL AND METHODS}

The digestibility and metabolizability of energy and protein digestibility of RS can be determined using the following regression model:

$$
\mathrm{Y}=\mathrm{b}_{1} \cdot \mathrm{x}_{1}+\mathrm{b}_{2} \cdot \mathrm{x}_{2}
$$

where:

$\mathrm{Y}=$ intake of digestible energy, metabolizable energy $(\mathrm{MJ} / \mathrm{d})$ or digestible protein $(\mathrm{g} / \mathrm{d})$;

$x_{1}=$ intake of energy $(\mathrm{MJ} / \mathrm{d})$ or protein $(\mathrm{g} / \mathrm{d})$ of the tested feed;

$\mathrm{x}_{2}=$ intake of energy $(\mathrm{MJ} / \mathrm{d})$ or protein $(\mathrm{g} / \mathrm{d})$ of the basal feed;

$b_{1}=$ digestibility or metabolizability of energy or protein digestibility of the tested feed;

$b_{2}=$ digestibility or metabolizability of energy or protein digestibility of the basal feed.

Two experiments were carried out, both on twelve growing pigs of the Landrace breed, with an average body weight of $55 \mathrm{~kg}$. In experiment 1 , the pigs were fed on a barley diet containing $5,10,15,20,25$ or $30 \%$ RS (Table 2). The energy and protein digestibilities of these diets were determined by the indicator method $\left(0.5 \% \mathrm{Cr}_{2} \mathrm{O}_{3}\right)$ with a four-day period of faeces collection preceded by a 14-day preliminary period.

In experiment 2 , the animals were given a diet containing rape seed and rapeseed oil meal produced from the same batch of RS as that used in experiment 1 . The proportion of rapeseed oil meal was constant $(18 \%)$. The proportion of RS in the diet increased from 0 to $5,10,15,20$ or $25 \%$ while the amount of barley decreased (Table 3 ). The diets contained not less than $16 \%$ crude protein and $0.83 \%$ lysine, which corresponds to the minimum level of these components in standard feeds for fatteners. The digestibility of energy and protein and metabolizability of energy of the diets were determined by classical method. The 14 days preliminary period preceded 4 days of faeces and urine collection. 
The rape seeds were mixed at a ratio $1: 1$ with barley and crushed. The classical methods were used for the chemical analysis of feeds, complete diets, faeces and urine. NDF and ADF were determined by the Van Soest method $(1967,1973)$ in a Tecator "Fibertec-System $M^{\prime \prime}$ apparatus. The amino acid composition of the seeds and rapeseed oil meal was determined following protein hydrolysis (Buraczewska et al., 1984) using a Beckman Unichrom analyzer and the total glucosinolate content by a modified Youngs-Wetter method (Byczyńska, 1971). The gross energy content of feeds, faeces and urine was determined by combustion of samples in a bomb calorimeter. Energy loss in gasses was not included in the calculation of metabolizable energy.

TABLE 1

Composition of rape seed and rapeseed oil meal

\begin{tabular}{ccc} 
Rape seed & $\begin{array}{c}\text { Rapesed } \\
\text { oil meal }\end{array}$ \\
\hline Data from literature & Present dita &
\end{tabular}

Chenical composition, \%

Dry matter

$95.1 \pm 1.7$

95.1

89.4

In dry matter:

$\begin{array}{lcrr}\text { Ash } & 4.9 \pm 0.4 & 4.2 & 7.7 \\ \text { Crude protein } & 22.5 \pm 0.4 & 20.6 & 37.4 \\ \text { Ether extrakt } & 43.4 \pm 1.7 & 45.3 & 3.7 \\ \text { Crude fibre } & 9.2 \pm 2.0 & 7.3 & 13.6 \\ \text { NDF } & 21.0 & 30.1 & 34.8 \\ \text { ADF } & 14.0 & 28.2 & 30.9 \\ \text { N-frec extractives } & 20.0 & 22.6 & 37.6 \\ \text { Oss energy, MJ } / \mathrm{kg} & 27.4 \pm 0.2 & 29.4 & 19.5\end{array}$

Total glucosinolate $\mu$ molig fat-liree

dry matter

$26-36$

22.8

5.5

Amino acids, g $16 \mathrm{~g} \mathrm{~N}$

Lys

$5.45^{2}$

6.55

5.48

Met

1.87

2.17

2.07

Cys

1.56

2.77

2.51

$\mathrm{Thr}$

4.63

4.79

4.52

Tyr

1.42

1.41

1.42

Val

4.42

6.24

5.72

Ileu

3.24

4.70

4.50

Leu

6.81

7.65

7.30

His

2.64

3.10

2.60

Arg

6.62

7.25

6.20

Phe

3.84

4.50

4.35

' Average - from Bourdon et al. (1990), rolling + moderate heating; Ochetim et al. (1980), micronisation rolling and Salo (1980), rape secd-low glucosinolate;

2 amino acid - from Ochetim et al. (1980). 


\section{RESULTS AND DISCUSSION}

The crude protein, fat and crude fibre contents in the seeds were similar (Table 1) to those of the low-glucosinolate RS used by Salo (1980), Ochetim et al. (1980) and Bourdon et al. (1990) in experiments with pigs. The levels of essential amino acids, especially lysine ( $6.55 \mathrm{vs.} 5.45 \mathrm{~g} / 16 \mathrm{~g} \mathrm{~N})$, were higher than in the seeds used in the study of Ochetim et al. (1980). With a similar crude protein content (in fat-free DM), the protein in rapeseed oil meal contained about $17 \%$ less lysine than seed protein $(5.48$ vs. $6.55 \mathrm{~g} / 16 \mathrm{~g} \mathrm{~N})$. This indicates for the particular sensitivity of lysine to the high temperature used during processing of rape seeds, which has also been demonstrated in papers by Grala et al. (1989) and Craing et al. (1981). On the other hand, rapeseed oil meal contained over 4 times less glucosinolates than seeds ( $5.5 \mathrm{vs.} 22.8 \mu \mathrm{mol} / \mathrm{g}$ fat-free DM), which indicates that a significant amount of this components is destroyed during toasting of oil meal.

TABLE 2

Composition and digestibility of diets (Experiment 1)

Group

SEM

\begin{tabular}{lrrrrrrr}
\hline Ingredients, \% & 5 & 10 & 15 & 20 & 25 & 30 & - \\
Rape seed & 93 & 88 & 83 & 78 & 73 & 68 & - \\
Barley & 2 & 2 & 2 & 2 & 2 & $2-$ \\
Vitamin-minral mixture & & & &
\end{tabular}

Chemical composition, \%

Dry matter

$\begin{array}{lllllll}89.7 & 90.2 & 90.2 & 90.9 & 91.0 & 92.0 & -\end{array}$

In dry matter:

Ash

Crude protein

Ether extract

Crude fibre

$\mathrm{N}$-free extractives

Total glucosinolate, $\mathrm{mol} / \mathrm{kg}$

Gross energy, MJ/kg

$\begin{array}{rrrrrrr}5.3 & 5.6 & 5.6 & 5.8 & 5.8 & 5.8 & - \\ 11.2 & 11.8 & 12.1 & 12.7 & 12.8 & 13.1 & - \\ 4.0 & 6.1 & 7.7 & 10.2 & 12.1 & 13.8 & - \\ 4.7 & 4.8 & 5.0 & 5.1 & 5.2 & 5.5 & - \\ 64.5 & 61.9 & 59.8 & 57.1 & 55.1 & 54.0 & - \\ 0.6 & 1.2 & 1.8 & 2.4 & 3.0 & 3.6 & - \\ 16.2 & 16.7 & 17.3 & 17.8 & 18.4 & 19.0 & -\end{array}$

Apparent digestibility: gross energy, $\%$ $\begin{array}{llllllll}78.4^{\mathrm{A}} & 78.2^{\mathrm{A}} & 78.0^{\mathrm{A}} & 78.2^{\mathrm{A}} & 76.8^{\mathrm{A}} & 73.3^{\mathrm{B}} & 0.32\end{array}$ crude protein, $\%$ $\begin{array}{lllllll}71.4 & 71.6 & 71.6 & 71.9 & 70.7 & 69.3 & 0.80\end{array}$

A, $\mathrm{B}-\mathrm{P}<0,01$ 
The level of nutrition, which differed up to $20 \%$ between each experiment, did not significantly affect the digestibility of energy and protein. No significant differences were found either between the indicator and classical methods of determining digestibility.

Increasing the proportion of RS from 5 to $30 \%$ (Table 2) and from 0 to $25 \%$ (Table 3) did not affect $(\mathrm{P}>0.05)$ protein digestibility, which was at least $70 \%$. A declining tendency of this parameter was observed only when the seed content exceeded $20 \%$. The results reported by Show et al. (1990) and Ochetim et al. (1980), who observed a decrease of the protein digestibility as early as at a $15-20 \%$ seed content in the diet, were not confirmed. These authors, however, carried out their experiments on weaned piglets, more sensitive to feed quality than $50-60 \mathrm{~kg}$ fatteners.

TABLE 3

Composition and digestibility of diets (Experiment 2)

Group

SEM

Ingredients, \%

Rape seed

Rapeseed oil meal

Barley

Vitamin-mineral mixture

$\begin{array}{rrrrrrr}0 & 5 & 10 & 15 & 20 & 25 & - \\ 18 & 18 & 18 & 18 & 18 & 18 & - \\ 79 & 74 & 69 & 64 & 59 & 55 & - \\ 3 & 3 & 3 & 3 & 3 & 3 & -\end{array}$

Chemical composition, $\%$

Dry matter

$\begin{array}{lllllll}89.6 & 90.1 & 90.3 & 90.8 & 91.1 & 91.1 & -\end{array}$

In dry matter:

Ash

Crude protein

Ether extract

Crude fibre

$\mathrm{N}$-free extractives

Total glucosinolate, $\mathrm{mol} / \mathrm{kg}$

Gross energy, $\mathrm{MJ} / \mathrm{kg}$

$\begin{array}{lllllll}5.9 & 6.0 & 5.9 & 6.1 & 6.4 & 6.4 & -\end{array}$

$\begin{array}{lllllll}15.9 & 16.3 & 16.6 & 17.0 & 17.3 & 17.7 & -\end{array}$

$\begin{array}{lllllll}2.5 & 4.3 & 6.7 & 8.4 & 9.8 & 12.6 & -\end{array}$

$\begin{array}{lllllll}5.9 & 6.0 & 6.2 & 6.3 & 6.7 & 6.6 & -\end{array}$

$\begin{array}{lllllll}59.4 & 57.5 & 54.9 & 53.0 & 50.9 & 47.9 & -\end{array}$

$\begin{array}{lllllll}0.85 & 1.45 & 2.04 & 2.64 & 3.23 & 3.83 & -\end{array}$

$\begin{array}{lllllll}15.9 & 16.5 & 17.1 & 17.9 & 18.5 & 19.3 & -\end{array}$

Apparent digestibility \%

gross energy

$\begin{array}{lllllll}77.5^{\circ} & 77.4^{\prime \prime} & 77.0^{\prime \prime} & 76.9^{\prime \prime} & 74.7^{\mathrm{b}} & 74.6^{\mathrm{b}} & 0.43\end{array}$

crude protein

$\begin{array}{lllllll}77.1 & 77.0 & 77.0 & 76.8 & 76.8 & 76.2 & 0.73\end{array}$

Metabolizability of energy, \%

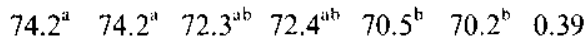

$a, b-P<0,05$ 
TABLE 4

Regression equations for prediction of digestibility and metabolizability of energy and digestibility of protein for tested $\left(b_{1}\right)$ and basal feed $\left(b_{2}\right)$

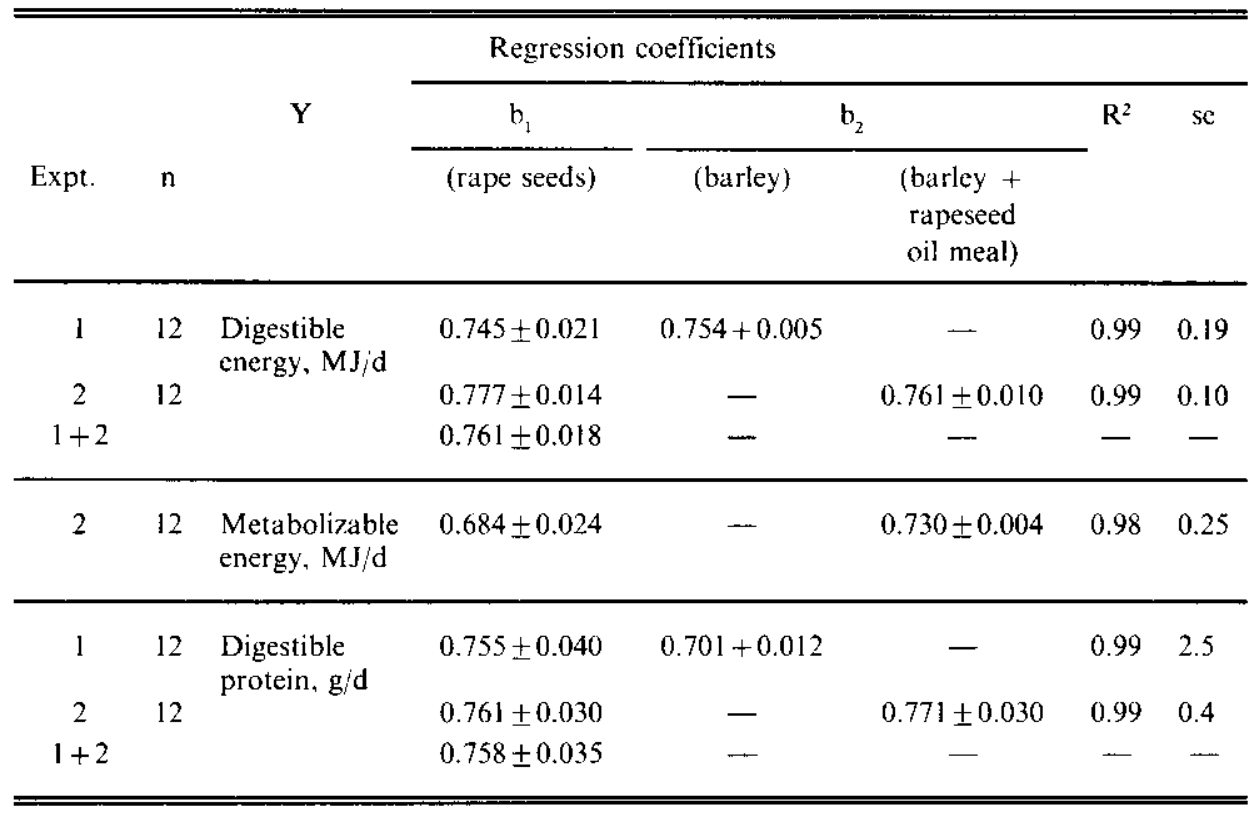

Model: $Y=b_{1} \cdot x_{1}+b_{2} \cdot x_{2}$

As a consequence of the higher protein content in the diets used in experiment 2 and containing $18 \%$ rapeseed oil meal protein digestibility was greater by $5.8 \%$ than in experiment $1(76.9$ vs. $71.1 \%)$; this is a know relationship (Bell et al., 1987; Charmley et al., 1987).

Energy digestibility was similar in both experiments and depended to a greater extent on the amount of seed in the diet than on the level of nutrition. The energy digestibility coefficients of the diets containing 5 to $20 \%$ of raw seeds were similiar (78.2 $\pm 0.2 \%$ ) (Expt. 1; Table 2). As the proportion of RS in the diet increased the energy digestibility in experiment 1 decreased: slightly at $25 \%$ and dropped to $73.3 \%$ at $30 \%$. ( $P \leqslant 0.01)$, while in experiment 2 the energy digestibility decreased after exceeding a $15 \%$ RS content (Table 3 ). This difference could have been caused by the higher crude fibre content in the diets in experiment 2 than 1 . The metabolizability of energy of the diets decreased as the proportion of RS increased, showing a slight tendency to change the ratio of metabolizable to digestible energy (from 0.958 to 0.941 ).

The energy digestibility found in this experiment was similar to the values obtained by Show et al. (1990) and Ochetim et al. (1980) for rations containing 
0 to $15 \%$ of RS. When a higher proportion of seeds was used, the results differed from those reported in the literature. Increasing the amount of RS from 15 to $30 \%$ decreased energy digestibility by about $5 \%$, while doubling the amount of seed in the study by Show et al. (1990) decreased in energy digestibility of the diet by $8 \%$. Ochetim et al. (1980) found an approximately $5 \%$ decrease in energy digestibility when the proportion of RS in the diet increased from 10 to $20 \%$.

The decrease in the digestibility of energy in the diets containing a high proportion of RS can be explained by their increased fat content. In our study (Expt. 1), fat digestibility of the diet with a $20 \%$ RS content ( $10.2 \%$ ether extract) was $66 \%$ and of the diet with a $30 \%$ RS (13.8\% ether extract) was $52 \%$ $(P \leqslant 0.01)$. The decreased digestibility of the ether extract was accompanied by a decline in the energy digestibility of the whole diet and, as a result, its concentration was less than expected. One of the reasons for the reduction of the digestibility of the ether extract in the diets contained a higher proportion of RS my below availability of oil contained in the seeds. Lawrance et al. (1978) showed that pigs digested fat contained in RS 14\% less than the extracted oil. A similar difference was found by Askbrant et al. (1990) in studies on 5 to 7 week-old chicks fed RS or oil extracted from them and added to the meal. In can be supposed that also the increase of crude fibre content was partly responsible for the decline of the energy digestibility. It was not, however, possible to distinguish the effects of these two factors, since the amount of fat in the diet increased together with its fibre content. This is in agreement with the results of Wieseman et al. (1987), who demonstrated a curvilinear relationship between the amount of added fat and the digestible and metabolizable energy contents in the diets fed to pigs.

It was therefore not proper to introduce all the balance data into equation 1. but only those which showed a linear relationship on seed content, i.e. to $15-20 \%$. The energy digestibility and metabolizability and digestibility of protein of RS $\left(b_{1}\right)$ and the basal diet $\left(b_{2}\right)$ are given in Table 4 . Although in the case of RS the energy and protein digestibility coefficients were found to be somewhat higher in experiment 2 than 1, this difference was not significant. Inclusion into the basal diet (barley + RS. Expt. 1) rapeseed oil meal (Expt. 2) did not affect the digestibility of the seeds itself. The data from Table 4 were used to calculate the digestible and metabolizable energy contents in RS (22.4 and 20.1 MJ, respectively) and the digestible protein content (156 g/kg DM). The values calculated for digestible energy were similar to those found in literature, while for metabolizable energy and digestible protein they were respectively $0.6-2.0 \mathrm{MJ}$ and $22-37 \mathrm{~g}$ lower than reported by Salo (1980) and Bourdon et al. (1990).

The results of these studies permit to draw the conclusion that when the RS content in the diet exceeds 15 to $20 \%$, a reduction in the nutritive value of the feed should be expected. A high proportion of RS in diets reduces the digestibility and metabolizability of energy, reducing the concentration of digestible and metabolizable energy. 


\section{REFERENCES}

Askbrant S.. Farrell D.J.. 1990. Utilization of oil in meals determined with chickens at different ages. PhD Thesis. (The concept of metabolizable energy for poultry). Swedish University of Agric. Sci., Rappor1 194

Bell J.M., Keith M.O., 1987. The digestibility of eanola meal by pigs as affected by age of pigs and characteristics of the diet. Proc. 7-1h Intern. Rapeseed Congress. Poznan. Poland. 7, 1647-1656

Bourdon D., Aumaitre A.. 1990. Low-glucosinolate rapeseeds and rapeseed meals: effect of technological treatments on chemical composition, digestible energy content and feeding value for growing pigs. Anim. Feed Sci. Tech. 30, 175-191

Buraczewska L.. Buraczewski S., 1984. A note on the determination of methionine and tryptophan. Proc. Vl-th Intern. Symp. on Anino Acids. Polish Sci. Publ. Warszawa. 47-50

Bycryńska B., 1971. The isothiocyanates and oxazolidinethiones determination in rapeseeds. Biuletyn IHAR Radzików. 5, 57-61

Charmley E.. Greenhalgh J.F.D.. 1987. Nutritive value of three cultivars of triticale for sheep, pigs and poultry. Anim. Feed Sci. Tech. 18, 19-35

Craing W.M.. Broderick G.A., 1981. Effect of heat treatment on arue digestibility in the rat, $i n$ ritro proteolysis and available lysine content of cottonseed meal protein. J. Anim. Sci. 52, 92-301

Gralà W.. Buracewska L., Gdala J., 1989. Wartość pokarmowa śruty rzepakowej "00" wyprodukowanej w różnej temperaturze tostowanià. Zesz. probl. Rośliny oleiste. IHAR Radzików. 1. 107-113

Lawrence T.L.J.. 1978. Effects of micronization on the digestibility of whole soya beans and rapeseds for the growing pigs. Anim. Feed Sci. Tech. 3, 179-189

Ochetim S.. Bell J.M.. Doige C.E., Youngs C.G.. 1980. The feeding value of Tower rapeseed for carly-weaned pigs. I. Ellects of methods of processing and of dietary levels. Can. J. Anim. Sci. $60.407-421$

Salo M.L... 1980. Nutritive value of full-fat repeseeds for growing pigs. J. Sci. Agric. Soc. Finland. 52 , $1-6$

Show J., Baidoo S.K.. Aherne F.X., 1990. Nutritive value of canola seed for young pigs. Anim. Feed Sci. Tech. 28, 325-331

Van Soest P.J., Wine R.H., 1967. Use of detergents in the analysis of fibrous seeds. IV. Determination of plant cell wall constituents. J. A.O.A.C. 50,513-530

Van Soest P.J., 1973. Collaborative study of acid detergent fibre and lignin. J. A.O.A.C. 56, $781-782$

Wiseman J., Cole D.J.A., 1987. The digestible and metabolizable energy of two fat blends for growing pigs as influenced by level of inclusion. Anim. Prod. 45, 117-122

\section{STRESZCZENIE}

\section{Wartość pokarmowa nasion rzepaku podwójnie ulepszonego dla tuczników}

Dwanaście wieprzków rasy pbz o średniej masie ciała $55+1,5 \mathrm{~kg}$, żywiono mieszanką zawierającą od 5 do $30 \%$ (dośw. 1) lub od 0 do $25 \%$ surowych nasion rzepaku (dośw. 2 ). Strawność diet oznaczono metodą wskaźnikową (dośw. 1) lub klasyczną (dośw. 2). W doświadczeniu 2 oznaczono również metaboliczność energii. Strawność pozorna białka ogólnego nie zależała od udziału nasion rzepaku w dawce, natomiast strawność i metaboliczność energii obniżała się po przekroczeniu 15\% (dośw. 2) lub 20\% udziału nasion (dośw. 1). Średnie współczynniki strawności i metaboliczności energii oraz strawności pozornej biakka nasion oszacowane metodą regresyjną przy ich udziale w dietach do 15 i $20 \%$ wynosiły odpowiednio: $76,1 \pm 1,8 \%, 68,4 \pm 2,4 \%$ i $75,8 \pm 3,5 \%$. Zawartósć energii strawnej i metabolicznej w $1 \mathrm{~kg}$ suchej masy nasion wynosiła odpowiednio: 22,4 i 20,1 MJ, a zawartość białka strawnego $156 \mathrm{~g}$. 